\title{
Community based pedagogy as an eye-opening for pre-service teachers' initial connections with the school curriculum
}

\section{Pedagogía basada en la comunidad como una revelación para las conexiones iniciales de los profesores con el currículo escolar}

\author{
Sandra Patricia Lastra ${ }^{1}$ \\ Norma Constanza Durán ${ }^{2}$ \\ Deyssi Acosta $^{3}$
}

\begin{abstract}
Citation/ Para citar este Artículo: Lastra, S., Durán, N. \& Acosta, D. (2018). Community based pedagogy as an eye-opening for pre-service teachers' initial connections with the school curriculum. Colomb. Appl. Linguistic. J., 20(2), pp. 209-229.

Received: 21-Feb.-2018 / Accepted: 12-June-2018

DOI: https://doi.org/10.14483/22487085.13047

Abstract

Today more than ever it is critical to guide future teachers in the direction of understanding how people participate and constitute social reality as a seedbed to create more significant language curriculums that respond to school students' needs and empower them to act more critically in their worlds. This article discusses the way pre-service teachers started to become aware of the need to establish relationships between community resources (linguistic, social, and cultural) and their role as individuals and teachers to enact critical pedagogy. This qualitative exploration was developed with three different groups of students in an English undergraduate program in a public university. Data were gathered by means of community mapping reports (Kreztmann \& Mckinght, 1993) and presentations, students' insights into community based pedagogy in teacher education (Schecter, Solomon, \& Kittmer, 2003), and pedagogical projects designed and carried out in the schools where they did the teaching practicum. The outcomes of this study brought to light how pre-service teachers began making connections between the principles of community based pedagogy and the language curriculum in the schools. Findings demonstrate the way they encouraged their students to explore their communities from different perspectives and promoted students' role of inquirers of themselves and their contexts.
\end{abstract}

Keywords: community based pedagogy, curricular connections, inquiry, local knowledge

\section{Resumen}

Hoy más que nunca es fundamental guiar a los futuros docentes en la comprensión de cómo las personas participan y constituyen la realidad social como semillero para crear currículos de lenguaje más significativos que respondan a las necesidades de los estudiantes y los empoderen para actuar de manera más crítica en los mundos que están inmersos. Este artículo muestra la forma en la que los docentes en formación comenzaron a tomar conciencia de la

1 Universidad del Tolima, Ibagué, Colombia. slastra.ramirez@gmail.com

2 Universidad del Tolima, Ibagué, Colombia. ncduran@ut.edu.co

3 Universidad del Tolima, Ibagué, Colombia. dacosta@ut.edu.co 
necesidad de establecer relaciones entre los recursos de la comunidad (lingüísticos, sociales y culturales) y su papel como individuos y docentes para implementar una pedagogía crítica. Esta exploración cualitativa se desarrolló con tres diferentes grupos de estudiantes de un programa de pregrado en inglés de una universidad pública. Los datos fueron recopilados por medio de informes de mapeo comunitario (Kreztmann y Mckinght, 1993) y presentaciones, perspectivas de los estudiantes sobre la pedagogía basada en la comunidad en la formación docente (Schecter, Solomon y Kittmer, 2003) y proyectos pedagógicos diseñados y llevados a cabo en las escuelas donde hicieron la práctica de enseñanza. Los resultados de este estudio revelaron cómo los estudiantes-docentes comienzan a establecer conexiones entre los principios de la comunidad y el plan de estudios de idiomas en los colegios. Los vínculos iniciales muestran la forma en que motivaron a sus estudiantes a explorar sus comunidades desde diferentes perspectivas y promovieron el papel de exploradores de sus propios contextos.en los estudiantes.

Palabras clave: conocimiento local, conexiones curriculares, investigación, pedagogía basada en la comunidad

\section{Introduction}

Language teacher education programs not only have the responsibility of guaranteeing the linguistic and pedagogical development of our pre-service teachers, but also the social commitment of helping them become critical readers of their society and agents of social transformation. As Freire (2005) states, in order to engage social transformation, learners need to realize that they are makers of culture and they are owners of reading and writing, able to read their realities. Achieving this endeavour requires pedagogies that take learners right to their realities and surroundings. As such, community based pedagogy becomes a significant framework through which our pre-service teachers can see their communities as spaces that offer rich sources to connect their syllabus and programs with the social, cultural, and economic areas that are part of the life of students and at the same time linked to language development.
In this sense, this article illustrates the ways in which pre-service teachers became aware of the need to establish connections between community resources (linguistic, social, and cultural) and their role as individuals and teachers to enact critical pedagogy. To accomplish this task, the initial steps are reported of student-teachers in the direction of being acquainted with and taking action based on community based perspectives. The findings become a springboard that enhance further research and curriculum adjustments in university courses in order to continue exploring the possibilities in the language classroom while allowing us to see a major impact in community inclusion, awareness, and understanding.

\section{Theoretical Framework}

This article provides an account of studies on community based pedagogies (Moll, Amanti, Neff, E Gonzalez, 1992; Sharkey \& Clavijo-Olarte, 2012; Warburton \& Martin 1999), funds of knowledge, local knowledge (Genzuk, 1999; Moll et al., 1992; Warburton \& Martin, 1999), the community teacher (Schecter, Solomon, \& Kittmer, 2003), and language teaching education (Murrel, 2001). These trends are strongly related to both future language teacher education and also going beyond the structural curriculum to provoke permanent meaningful learning. In addition, these trends are of paramount importance to determine how much the existing knowledge of community beased pedagogies, funds of knowledge, local knowledge and the community teacher lead preservice teachers to a clear-cut prediction of the way they carry out their classes using their own as well as natural resourses to focus day to day school practices.

\section{Community Based Pedagogies}

The term community is defined by dictionary. com as "a group of people living in the same place or having a particular characteristic in common, or a locality inhabited by such group." A community in the particular case of this article is the place, the neighborhood, or the block where students belong or live together, share ideas, preferences, buy, sell, or play. The community is a vital part of the teaching 
and learning process as well as a fund of knowledge (Moll et al., 1992). Similarly, the connection between the knowldege, the practices, and the curriculum are under the consideration and appreciation of the community in which schools are located and students and their families inhabit. (Sharkey \& Clavijo-Olarte, 2012). Community based pedagogy (CBP) involves the knowledge of the local communities, beliefs, constructs, and perceptions that all the people who belong to that community hold and share through everyday contact. According to Warburton and Martin (1999), "CBP includes the way people observe and measure their surroundings, how they solve problems and validate new information, the processes whereby knowledge is generated, stored, applied and transmitted to others" (p. 1). In Sharky and Clavijo-Olarte's (2012) perspective, CBPs are curriculum and practices that reflect knowledge and appreciation of the communities in which schools are located and students and their families inhabit. This methodology offers the opportunity to encourage future language teachers to connect theory and practice and to focus on self-directedness and self-awareness. Understanding the implications of these approaches, and making decisions about how to appreciate the sources that the communities offer, becomes a challenge for this new teachers generation. At this point Genzuk (1999) established that "the community funds of knowledge utilizes the notion of assisted performance, what a child can do with help, with the support of the environment, the others, and of the self" (p. 9). In this way, former teachers have the urgent need to prepare future language teachers to be conscious and aware of what they are learning to make informed decisions about their own learning (Sinclair, McGrath, \& Lamb, 1999).

\section{Funds of Knowledge}

Oughton (2010) points out that although the original conceptualization described these funds as labor related skills shared within and across households, some scholarship has shifted the location to individuals, expanding the nature of such funds to include interpersonal, communicative, and meta-cognitive skills. Funds of knowledge are events, activities, and characteristics people use while doing an activity. They are lived experiences of household histories and practices. So, in that way, funds of knowledge as community information become knowledge skills and experiences that students bring to learning from their culture, home, and community (López, 2010). On this matter, Genzuk, (1999) affirms that funds of knowledge are constituted through events or activities. That is, “... are constituted through events or activities" (p. 9). Those events are not under the domain of people but their distinctive ways of doing activities (Mall $\mathcal{E}$ Geenberg, 1990, as cited in Genzuk, 1999). At this point Genzuk (1999) states that:

\section{Knowledge is therefore obtained by the children, not imposed by the adults... The notion of culture is a dynamic entity, not simply a collection of foods, clothes and holidays, but a way of using social, physical, spiritual and economic resources to make one's way in the world. (p. 10)}

\section{Local Knowledge}

Local knowledge is a collection of facts and relates to the entire system of concepts, beliefs, and perceptions that people hold about the world around them. Operationally, this refers to "the way that people observe and measure their surroundings, how they solve problems, and validate new information. It includes the processes whereby knowledge is generated, stored, applied and transmitted to others" (FAO, 2004, n.p.). In this respect, Genzuk (1999) states that "a review of the literature suggests that to be an effective teacher, you need an in depth knowledge of the subject matter, a repertoire of teaching strategies and a deep knowledge o the culture and history of the students you are teaching" (p. 11).

\section{The Community Teacher}

The term community teacher refers to any teacher who teaches any area of knowledge but whose central point or resources of teaching is the community. In this regard, Murrel (2001) affirms that "a community teacher possesses contextualized knowledge of the culture, community, and identity of the children and families he/she serves and draws on this knowledge to create core teaching practices necessary for effectiveness in diverse settings" (p. 51). 
Community-situated pedagogies posits community as a curriculum resource and challenges to design and implement pedagogies based on community knowledge (Schecter, Solomon, \& Kittmer, 2003).

\section{Language Teacher Education}

Basic concepts related to the tendencies of working with the community are core issues in language teacher education. That is due, in part, to the fact that teaching and learning are understood as social activities which guide teachers to consolidate the relationship between the profession of teaching and the role of the community in the learning experience. Teachers have understood that the tasks of teaching and learning imply making curriculum modifications to include all funds of knowledge provided by families and communities around the school. In addition, through teaching, the teacher becomes an investigator of challenging situations to help their students and impact the community. Research helps teachers to innovate and make contributions to the school curriculum. On the other hand, Murrell (2001) highliths the importance of supporting teaching-learning activities with a community-based practice and argues that an accomplished teacher "possesses and works to build on knowledge of culture, community, and identity of children and families as the core of his/ her teaching practice" (p. 2).

\section{Methodology}

\section{The Study}

Exploring pre-service teachers understanding and incorporation of knowledge of local communities in language teaching and learning motivated us to rely on a qualitative exploratory design. This allowed us to explore explanations, words, concepts, and realities with the expectation of offering new ways of seeing and perceiving how these realities were constructed. In other words, exploratory research provided us the possibility to make sense of the world, offering new approaches and angles to find new alternatives (Reiter, 2017).
By observing and analyzing realities from surrounding contexts and communities as well as from different angles, we sought to go deeper and unveil the pre-service teachers' perceptions of the local resources available in their communities and how they characterized their own role as teachers as they explored their communities. Additionally, we sought to describe the ways in which pre-service teachers become aware of the need to establish relationships between the community resources (linguistic, social and cultural) and their role as individuals and teachers to enact critical pedagogy. As such, we address the following research question: How do EFL teachers in university-based education programs understand and incorporate knowledge of local communities as resources for language teaching and learning?

\section{Participants and Data Collection Instruments}

Universidad del Tolima, the only public university of the region, holds approximately 19,000 students and offers 27 academic programs. The School of Education is one of the biggest academic units of the institution, which in turn is constituted by six undergraduate programs such as social studies, science, mathematics, Spanish, physical education, and English — the focus of our study.

Fifty-six participants enrolled in this ongoing study from three different courses: Research Seminar I, didactics I and Practicum III. The participants were pre-service teachers from sixth, seventh, and tenth semester respectively of the undergraduate program in English. Practicum III students are in the last semester of the program and in the final stage of their practicum process. They have completed two research seminars and two didactics courses, and most of them are already working as part time teachers at different language centers within the city.

\section{Instruments and Procedures for Data Collection}

Participants started the process reading about some experiences of teachers at public institutions related to community based pedagogies. After discussing in class and becoming familiar with the 
principles and foundational bases of the framework, they did an initial exploration of the university community in order to identify and analyze assets and realities while experiencing the process of mapping the community as one of the moments of this framework. Thereafter, the discussion took place in class as a result of sharing their findings and reactions to what they could observe. Students explored the university community as a source for their curricular construction and experienced the possibilities of making curricular connections related to language teaching and learning. As a conclusive stage, students had the opportunity to write a narrative in which they talked about the experience and the most significant insights that they had gained.

Several of the Practicum III students decided to follow the community based pedagogy framework in their own teaching practice since they had to choose the framework or design they preferred in order to carry out a small-scale research project as a requirement of the course. In this way, five practicum students developed significant projects based on the local community.

Data were collected by means of four instruments:

1. Students' reports of their mapping exercise and photographic evidence: Students presented their findings orally and then shared their perceptions from the exercise and of what they identified within the community.

2. Students' narratives: Once students finished the process of mapping the community and after having the sharing and discussion time in class, they wrote a narrative about their feelings, insights, and more significant lessons from the experience. Practicum III students also wrote about their projects and what they were able to draw from the implementation of the community based pedagogy.

3. Practicum students' projects and oral and written reports of the progress and development of the project: students planned and carried out community-based projects throughout their practicum and shared the final results and conclusions in a local event held by the B.A. in English program. In this event, students shared their findings and the process they lived when implementing community pedagogy.

4. Interviews with cooperating teachers from public schools in which the students completed their practicum. We decided to interview these teachers in order to inquire as to their perceptions of the projects that pre-service teachers developed and their insights in terms of teaching and learning.

From the very beginning of the process students who participated in the project authorized the use of the information provided through the data collection instruments and agreed to participate in the study. They were, in advance, aware of the objectives and the general dynamic of the study.

\section{Data Analysis}

To analyze our data, we used grounded theory which allows the data to bring to surface significant results of the implementations done in three different courses. The exploration of assets at the university, the students' papers, and the outcomes of practicum projects were read several times as we used color coding to identify recurrent patterns and themes in the different instruments applied in the courses. The individual analysis of the instruments was compared and contrasted to triangulate and verify the findings. The themes that came into view led to categories that became evident after the analysis. These themes included: raising CBP awareness in language teacher preparation courses, understanding what a community teacher is, and community oriented practices as a path for pre-service teachers reinvention of the language curriculum.

The three categories explain the different phases undertaken in this study such as (a) the way students were familiarized with community based pedagogy principles and procedures; (b) The initial interpretations and understandings of the preservice teachers with respect to their role as teachers and individuals; and (c) what the implementations in 
the teaching practicum revealed pertaining to curricular innovations and new perspectives about language teaching when community members come to the center of decision making and social agency.

After analyzing the data and determining the three categories, we as researchers realized that the findings revealed a sequence and an implicit process of community based pedagogy understanding and implementation. The two first categories revealed how CBP was eye-opening in terms of raising awareness and unveiling more significant teachers' roles and a sense as individuals. These issues were strongly evident in students from the Research Seminar and the Didactics course. The third category, which deals with the curricular connections between CBP and the curriculum, was visible in students from practicum III who could implement and reflect on their practice. This important outcome encouraged us to start thinking about connections among the courses in order to establish a sequential process when exploring and implementing community based pedagogy.

\section{Findings}

\section{Raising Awareness}

One of the main challenges of language teacher educators is to guide future language teachers to be independent while focusing them towards selfdirectiveness and self-awareness. Throughout the day-to-day training, preservice teachers learn the theoretical foundations on how to be successful in their profession, but it is through practice that they experience the dynamics of the classroom, to know and understand their students and the different pedagogies to meet the student's needs. Additionally, raising future language teachers' awareness has been a matter of proving different pedagogies, strategies, and resources which helped them not only to be informed about new pedagogical and didactic trends, but also to put hands to work driving the preservice teachers to search within and include the communities, funds of knowledge, and the local knowledge into the school curriculum and language teacher education. To be aware of the implications of these new approaches and to make decisions about appreciating the sources offered by communities are a challenge for the new preservice teachers generation.

The B.A. in English program offers an array of courses $^{4}$ to inform and train students on observations, reflections, decision making, design, and implemention of research projects. In these courses, they explore and include the community, the local knowledge, and resources around the school to improve and advocate for imroved, inclusive education where children have equal opportunities. In this sense, participants "re-explored" the university with unprejudiced eyes, took pictures, and interviewed people from assets they found interesting or wanted to know more about. This exercise appeared enlightening and revealing with respect to the university life and structures that support and make it work. Here there are some of the comments made by the students after the experience:

By mapping the community into assets, the students can have wider idea about their community and really know it. Raising awareness on how important, the community is and how vital is each one in it. I could even see it with my bare eyes when doing the experiment at University, where my group and I found out the people we get to see every day and that many times we take for granted are living behind masks. At the end, we could appreciate their jobs and realize they are not random people working, but they could be the solution for many problems at university and vital for its functioning. (S1)

The reflections above show the pre-service teacher's own awareness and critical point of view about what happened inside the university community since they took the observation as the opportunity to denounce aspects (the poor field sports) that apparently work but that represent a threat to those who use them. Also, pre-service teacher agency is evidenced when arguing against the problems identified in the mapping. After the

\footnotetext{
4 These include, for example, didactics, research seminar I and II, practicum I, II and III, and aplied linguistics
} 
exercise of observing and mapping the university, the pre-service teachers expressed not only the emotion to have had the opportunity to practice how to observe, but also to know about different issues surrounding the university that they did not know or paid little attention to. Observing, mapping, and appreciating local resources and becoming aware of all the resources that the environment offers gave them the chance to value and include the pedagogy of community based approaches when planning their classes and also replicating the work with their students at the school context. It was also eye-opening for the connections they should bear in mind when going to their practicum in the schools. The following are some examples of students' reactions. Figure 1 shows one of their concerns identified during the mapping exercise:

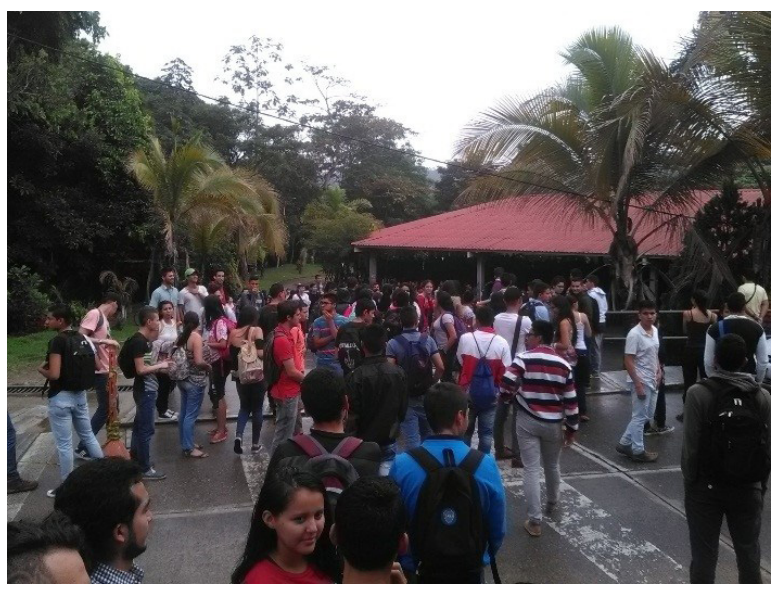

Figure 1. Students going to the restaurant of the University.

"Students constantly complain about the lack of organization when receiving the service, but highlighting the quality and balance of food" (S3). Pre-service teachers also noticed the lack of order at the time of queuing and waiting for their turn in the restaurant. To this respect, one of the students argued, "I had to shout at some students who were disrespecting those who stood in line to be served." Raising awreness of their community encouraged the pre-service teachers not only to become sensitive to their sorroundings but to expand their views as future teachers. This aspect is discussed further in the following section.

\section{Understanding what a Community Teacher is}

As a result of becoming aware of the world outside and all of the resources provided by the university community, pre-service teachers drew significant conceptions about who the teacher is within the CBP framework and they were able to see the possibilities to link community knowledge with their language teaching exercise.

Through CBP, the pre-service teachers saw themselves as social agents and arrived at the conclusion that they cannot be outsiders anymore, but as teachers, they need to be part of that educational community in order to be able to understand it and connect it to the classroom. As one of the students states in his narrative about the way he began seeing his/her students, "they are not just someone in the community but they are community" (S4). After getting involved in the community, our students felt they were not external actors but saw themselves as part of it. In this respect a student stated, "we as teachers belong to the community and society, and we are responsible for the warranty of all children and teenagers rights regarding their well-being... It is a moral responsibility" (S5). One more student argued, "CBP allows living the reality of the community where the exercise is being carried out; it is to know an academic world that at a given moment reaches the teacher directly or indirectly as a part of the educational community" (S6).

Pre-service teachers understand that the teacher's role is not tied to a classroom but it goes beyond the walls and the contents they develop in class. Our pre-service teachers see themselves as community teachers and coincide with the description coined by Murell, (2001) who described the community teacher as one who spends quality time in the community where he or she is going to teach in order to better serve his or her students. This vision entails some responsibilities for teachers. First, they need to know the social realities students face every day, and second, they must feel committed to providing solutions and proposals to improve those conditions.

Teachers have the moral responsibility of becoming closer and exploring collaboratively the 
school community. From this perspective, teachers are no longer observers of the realities but need to look for strategies to generate agency on themselves and those who they teach. They cannot be quiet or passive to the students' realities but need to show them and empower them with alternatives and other options in life. In this way, teachers become guarantors of children's rights. In this respect, one of the participants expresses in her narrative the following:

It is our duty as human beings that are part of the community to take an active role in the accomplishment of all students' rights. We must: know, respect, and share these rights, protect them in case they are being threaten, report any violation of these rights and help the authority in the application of them. (S7)

In these postings, we observe that CBP works as an eye opener for pre service teachers about their role as teachers. They define themselves as social agents that have the richest resource on their hands; they are able to see the community as a source of knowledge, a source that can provide interaction, opportunities to reflect, and take purposeful actions when necessary. This means that community teachers' knowledge will be nurtured by reflective experience, cultural knowledge, and critical inquiry (Murrell, 2001).

In addition, getting to know the community allowed pre-service teachers to build rapport not only with students but also with the whole community. As such, there was an adequate and comfortable atmosphere for everyone in the classroom, in the school, and in the community. Similarly, this rapport built real communication among students and teachers due to the realistic perspective, understanding of their reactions, ways of thinking, interests and concerns, etc., all of which will result in building strong relationships in which affection will be the motor. In this respect, some pre-service teachers said:

Participants get to know the environment they are surrounded by. Besides, teachers can observe the different points of view from their students and not only build rapport with them, but with the whole community, generating an adequate and comfortable atmosphere for everyone. (S10) That it is very important to establish relations of affection with the school community and the other people who live in the place where the school is located because only in this way we can know exactly what is happening with the students. (S11)

Behind students reflections there is a conception which, perhaps hidden or tacit, is the place of feelings, emotions, and affections in the process of teaching and learning. Almost all the pre-service teachers' reflections connected their experiences and their role as teachers and their job with appreciation for students, getting closer to their realities, and demonstrating respect and love, among others.

In conclusion, we see that for these preservice teachers, the CBP experience moved them to read the community critically, which implies questioning reality, raising awareness, transforming self, and rewriting the world (Medina et al., 2015).

\section{Community Oriented Practices: A Path for Pre-service Teachers to Reinvent the Language Curriculum}

From the standpoint that curriculum design and implementation involves decision making requiring a knowledge base which at the same time allows for the connection with the communities involved and the expansion and understanding of them, this category shows pre-service teachers' experimentations with the incorporation of unused or yet invisible assets such as students' families or the students' feelings and perceptions of themselves to promote learning. The scenarios that will be presented highlight how the future teachers began constituting their knowledge base supported by the need to transcend the role of the language teacher and to establish links between daily work and the communities that shape and nurture students' growth (Schecter, Solomon, \& Kitmmer, 2003).

This may seem a daunting endeavor when most classrooms, despite their intended purpose of preparing learners for life outside the classroom, 
promote insulated practices that do not have reciprocal connections with their outer world (Lave \& Wenger 1991; Matus \& McCarthy, 2003). In order to promote more constructive experiences that potentiate cultural resources of families and local communities to the benefit of students' learning, it is paramount to redefine the classroom as a curricular space where the construction of communities of practice (Wenger, 1998) is at the core, where teachers and learners co-construct together and exercise agency to the point the students become cognitively challenged and engaged (Graves, 2008) to work with and within their own communities.

As it was described in the forming courses, practicum III students were exposed to the practical work of inquiring about university assets as their immediate community exploration source. The excerpts below show an additional view of the student teachers who in turn start conforming and strengthening their own and growing funds of knowledge as teachers, which will inform them subsequently to make curricular decisions and shape their professional lives. Thereby, the preservice teachers involved in this exploration and the activities done to raise awareness about the community orientations did not hesitate to express their amazement and revelations of what seemed to them a potential alternative to shape their projects. In this respect, a practicum III student comments "this project will not be focused on teaching just English but it will be focused on teaching them to read and comprehend the world better" (S2).

This proposal provides me with a wide range of valuable and convenient tools that as preservice teacher I could implement them in my practicum. At the school where I am teaching, some problems related to drugs, dysfunctional families, insecurity, low students' academic performance etc, have been presented around and inside the school. (S1)

Next there is a description of two different projects and their respective outcomes which display the different curricular connections preservice teachers started to make between the local sources such as the students themselves and their families. This was evidenced through the design and implementation of a project with impact in the classroom or the school, as a course requirement.

\section{The Projects}

Being certain about the nature of their projects framed within the community as a source, it was not enough for the pre-service teachers involved in this study and so they decided to implement a needs analysis that would allow them to focus more acutely on potential areas that they had identified in learners and schools in their former university courses. As a consequence, they started to collect data through questionnaires and informal interviews with the students. This process allowed the teachers to identify the themes of their projects.

The following are some of the titles of the projects that pre-service teachers came up with, but due to the teachers' strike that year, only two of them were able to follow a consistent process and take the project to the end. To provide a detailed account of what the pre-service teacher's community oriented implementations consisted of, we focus on the following two projects: Valuing the difference and Family structure's effects on eight grader's performance from a public school.

\section{Valuing the Difference}

A first group of preservice teachers wanted to undertake the topic of raising awareness of tolerance and acceptance towards classroom diversity in eight graders at a public school. For them, this was an area of concern which emerged from their own observations and growing concern in the school, where signs of discrimination, exclusion, and bullying were becoming frequent. They first implemented questionnaires to dig into students' feelings about certain issues; in this case, about themselves as human beings with differences. They complemented this information with interviews. Next, the students took part in a mapping activity in which they exhibited and group photo shoots of their interests, likes, dislikes, and hobbies. By mapping, the preservice teachers could explore students' concepts related to diversity and beauty and carry out a project that was depicted in a didactic unit (see 
Appendix 1). One of the salient aspects in this design is the connection of the topic with the syllabus for the course, within the framework of related videos, and self-esteem activities in which the students practiced descriptive adjectives to talk about their personality, abilities, and appearance in different tasks proposed along the project.
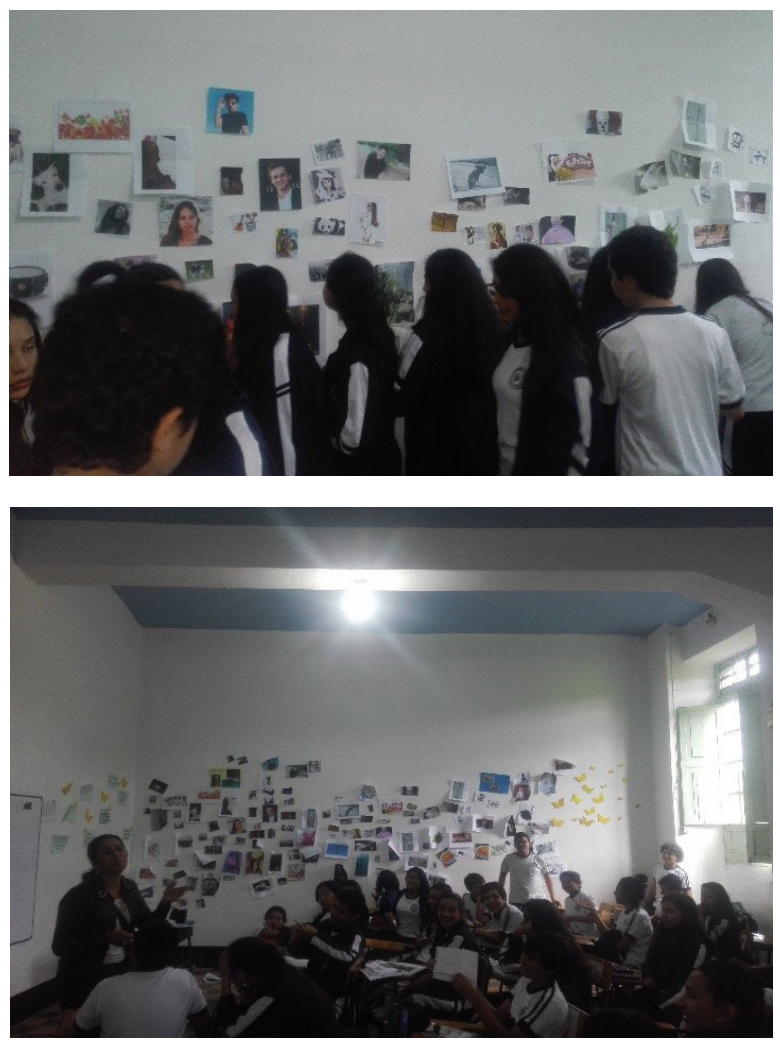

Figure 2. Students' mapping.

\section{Outcomes of the Project}

For this project, there were two major accomplishments as a result of exploring students' self-value and enhancing respect and tolerance towards diversity in eight graders. The first was an eye-opening experience for the preservice teachers when students became the center of the whole process, and through digging into their needs, perceptions, and views about themselves and about others, opened the door to make sense of, redefine, and redirect the language curriculum as a broader space for learning and growth as human beings. These are some of the reactions that practicum students who directed this project stated in their final written report.

It is very common to find law levels of selfesteem among teenagers nowadays and eight graders at this school, were not the exception. This project aimed to work on prompting the students' self-esteem through the implementation of some teaching principles from community based pedagogy, an approach that sees the students' context as a source of curriculum. Sometimes we struggle with ways to include what students offer in classes and even do not consider what the local resources may present to us, so we can insert those features and recreate and improve curriculum. (S2)

Through this teaching experience we could grasp the idea of how significant is to keep a balance between the curriculum and the students' needs, considering that teachers generally just only center their practices on the topics that must be taught and hardly ever get to realize about their students' needs. Including students' interests, their beliefs, previous knowledge within the curriculum is possible. A truly demanding task, yet possible, resulting in meaningful and contextualized learning that learners will always remember and possibly change their lives. (S3)

Another remarkable accomplishment has to do with the way pre-service teachers and their students see the role of the foreign language in the implementation of community oriented tasks. Their excerpts evidence that the primary goal was not the teaching of the language per se, but it became a means for the students to convey ideas, feelings, and emotions.

After the implementation of the project I have come to realize on the importance of using language not only for linguistic or educational purposes but also as a tool or vehicle to prompt different values, such as respect, tolerance, responsibility and many others that somehow humanity has been losing lately and Colombian high schools are not the exception. (S4) 
Finally, a related fact that needs to be highlighted at the end of the project was the fact that the students exhibited their selfies and their notes about themselves in the schoolyard where different members of the school passed by and observed and even made positive comments such as, "muy interesante la actividad professor."

The following is one of the excerpts from the pre-service teacher who commented proudly on what his students did.

The students presented their photos to other members of the school community. While they were presenting, there were messages and prompts that have to be highlighted because they wrote beautiful descriptions about them using what they saw in in the English class, some of the students came up with awesome ideas:

I like my eyelashes, it does not matter that they are short.

I love my smile

I like my solidarity. I love me.

I love my humor, I'm good at English and math.
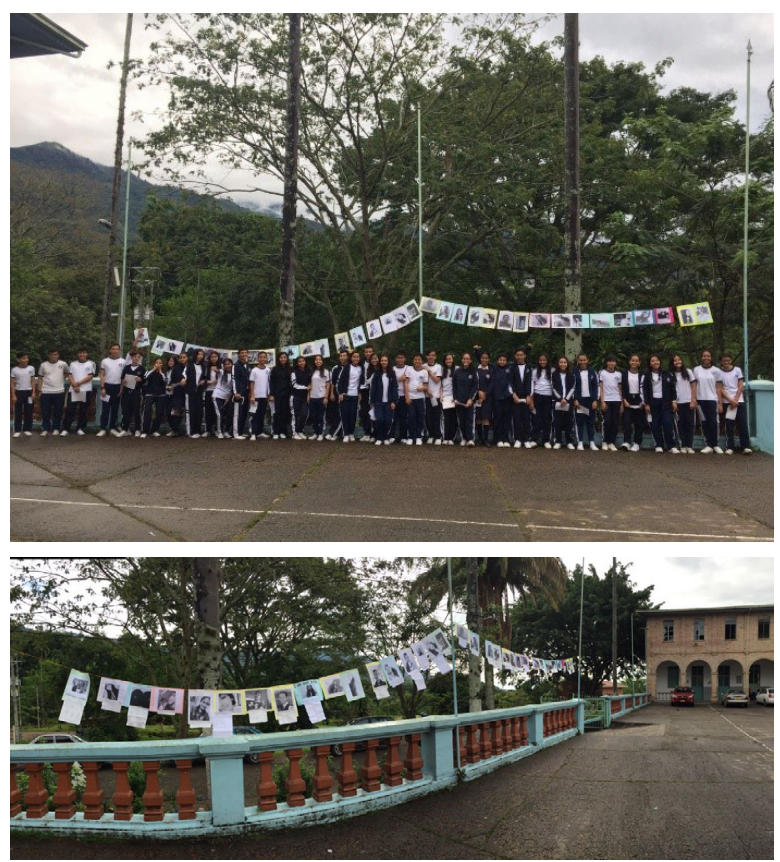

Figure 3. Final products exhibition.

\section{Family Structure's Effects on Eighth Grader's Performance from a Public School}

The second project conducted by another group of preservice teachers tackled a common issue in different grades in two different institutions which was the influence that different family structures had on eighth graders by portraying their characteristics and fostering ways to involve families more in students' academic activities. Suleman, Hussain, Akhtar and Khan (2012) suggest that "family setting and background is playing a vital role in strengthening or devastating student's academic performance. Peaceful and favorable environment within the home has a significant effect on the student's performance" (p. 235).

To begin, these students implemented a needs analysis through a short questionnaire that determined those students with an incomplete family structure. The analysis demonstrated that there were students living with siblings, grandparents, or just one parent. The answers obtained through the implementation of different instruments such as interviews and journal writing on the students' part were the confirmation of initial analysis and the conclusions which became the gateway to new action plans. The findings out of the three instruments were confirmatory in the sense that they expanded and went beyond the initial information collected through the questionnaires.

The journals whose purpose was to know their students, their experiences, and interpersonal relationship and to recognize their family structure evidenced that when students were asked to write an entry about their weekend that reflected all the activities done during the day, the student teachers reported the following:

A very remarkable and important aspect when reading the journals was the lack of family support in the course of their daily lives. In most journals, the participation of parents in the activities of the day was very little or scarce, even people outside the family were named, for example, friends or neighbors. (S5 final report) 
Regarding the students' journal, preservice teachers highlighted: "Most of the journals seemed made with dedication and commitment. To be honest, we really loved and were delighted to know the interest of our students in sharing their lives with us" (S6).

The didactic unit they designed showed their plan and procedures (see Appendix B). In this plan, the connections are evident that the students made with guidelines set in the country for the schools like the standards and so called DBA. These include basic learning rights that show the link between the foreign language and the chosen topic.

\section{Outcomes of the Project}

The biggest attainments of this project considering its nature are, on the one hand, the reinvention of the English class and curriculum as a space to get a close up to the school students and their family dynamics proved to have a tremendous influence on the students' performance and learning.
This is evidence in the following conclusions that pre-service teachers wrote in their final report.

Family involvement allowed us to focus more on the task of teaching children. Also, by having more contact with parents, we learned more about the students' needs and home environment, which is key information that we can take into account for preparing classes and future activities. (Group conclusions on final paper)

As teachers, it is necessary to develop curricula that have local relevance. By using community-based pedagogy it is possible to know the influence of pedagogies focused on students and their families. Likewise, there are no limits to the expected results, and it does not limit pupils' participation. (Group conclusions on final paper)

On the other hand, a second accomplishment of this group has to do with their growing sensitivity to understand the students' social reality. In this
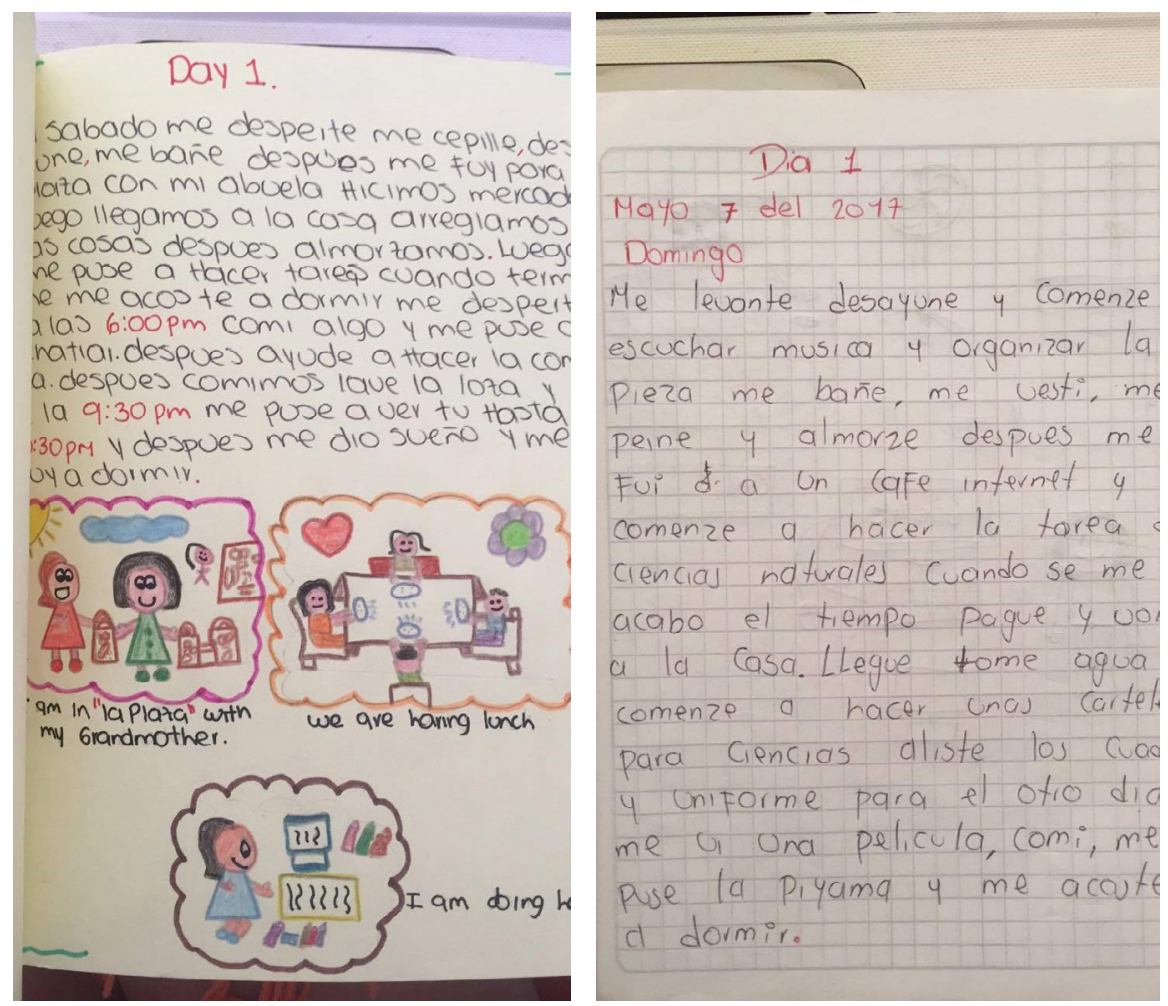

Figure 4. Student's journal. 
way, a strengthened view emerged to make more informed connections between language teaching and social issues that they may encounter in their future professional experiences as it is supported in the following excerpt taken from a student teacher's reflection:

The information obtained was very beneficial to our research and it was really possible to know about our students when they are not at school. Many conclusions are related to the lack of parents' interest in the development of their Children's activities; they performed their homework alone and usually spend time with people outside the family, with the exception of a few students. (Group conclusions on final paper)

\section{General and Common Outcomes of the Experience}

Although the two projects could have gone further and made more evident the role of students as researchers, they made interesting accomplishments and unveiled realities upon which they took action with the purpose of intervening in the areas that were causing problems or difficulties in the students' learning or academic performance. In this way, it was evidenced that the preservice teachers started shaping a profile as community teachers turning the deficiencies into opportunities (Murrel, 2001).

One of the most significant gains for the preservice teachers at the time of making curricular decisions in connection with the design of community oriented tasks was that they became more sensitive to students' needs as a starting point in all projects. This allowed them to connect to the personal, cultural, and social influence of the environments that surrounded the school students. This fact reinforced in the future teachers the relevance of addressing needs and interests before they embark in any curricular decisions as they saw students engaged and genuinely active in the different activities proposed. This is supported by Rincón and Clavijo-Olarte's (2016) who assert that community-based pedagogies are outside school practices, life experiences, and assets that learners and teachers who want to have a deeper understanding of the local places in which their students interact bring into the classroom in order to enlighten class dynamics and curricular constructs.

In both projects, the pre-service teachers discovered connections and possibilities to bring communities into the classroom and the curriculum. These connections drove them to innovate the nature of their projects, the role of language teaching, and to included more creative alternatives. Such alternatives brought together the lives of the students and the contexts in which they were immersed as it was clear in the didactic units they designed without following a course book or rigid curricular agendas. On this matter, Sharkey (2012) affirms that "curriculum can come from the interaction between student, teachers and experiences; it does not have to come from a textbook or in a box of materials from the district office" (p. 12).

The two projects also made noticeable the role of the language teacher and the role of the teacherresearcher of their communities, which is an area that needs further encouragement in teacher education programs as a way to foster substantial impact in classroom and teaching practices in general. Through continuous and extensive exposure to the implementation of this type of pedagogical orientations in the teaching practicum courses, the role of the researcher will be very likely passed on to the school learners, too, with meaningful results.

\section{Conclusions and Implications}

As we walked the path with our pre-service teachers, we realized that the concept funds of knowledge also applies to the knowledge base of future teachers since their histories and former experiences guide and shape the decisions they make in their teaching practices and hopefully later in their professional lives. It is necessary to continue in the exploration of community responsive pedagogies with pre-service teachers. Research has shown that many teacher education programs pay little attention to the differences among preservice teachers' experiences, cultural backgrounds, and needs, and to how the valuable resources they are for learning 
in their teacher education courses (Gupta, 2006). As a consequence, this issue becomes a challenge for teacher education programs to incorporate preservice teachers' experiences, interests, concerns, social awareness, and the community they represent in the process of becoming a teacher.

The first encounters of the pre-service teachers with this perspective reinforced their sensitivity to their students' needs and opened the door to new possibilities and new ways of seeing their learners, their families, and the environment that surrounds them. It let them see and employ other forms of working with and for the curriculum as vehicles that should facilitate social network that bring "living knowledge" from the community to the classroom (Moll, 1992). This experience also demonstrated the need to develop extensive foundational knowledge in the pre-service teachers regarding social, psychological, cultural, political, and economic forces that intervene in students' lives, to redirect practices as real social agents that take advantage of the potential that community offers to conceive and face the world differently.

A final lesson learned is to uphold a more collaborative effort and systematic work between the members involved in teacher preparation during the practicum. This collaboration includes advisor teachers from the schools and the teachers from the university in order to promote sociocultural perspectives such as understanding of community based pedagogies and to enhance more coherent work and eventual growth as team members.

\section{Drawbacks and Challenges}

1. Due to school dynamics and university procedures, pre-service teachers were not given enough time to develop their projects as initially planned. During the progression of the project they had to rush and suffer permanent interruptions derived from teachers' strikes and continuous institutional celebrations. Together, these brought dissatisfaction and frustration on the student teachers' behalf.

2. It is necessary to look for strategies to work with practicum supervisors at schools in order to make them aware of the procedures and requirements that pre-service teachers have to accomplish during the practicum courses.

3. The imposition of established curricular directions and fixed syllubuses at school tend to constrain the pre-service teachers' possibility to contribute and innovate both at the curricular and methodological level. It is necessary to find points of encounter between the two agendas through permanent dialogue and collaborative work.

\section{References}

Reiter, B. (2017). Theory and methodology of exploratory social science research. International Journal of Science and Research Methodology, 5(4) 129-150.

Freire, P. (2005) Teachers as cultural workers: Letters to someone who dare teach: United States of America: Westview Press.

Genzuk, M. (1999). Tapping into community funds of knowledge. InEffectivestrategies for English language acquisition: Curriculum guide for the professional development of teachers grades kindergarten through eight (pp. 9-21). Los Angeles, CA: Annenberg Metopolitan Project/ARCO Foundation.

Glavanis, P. (2014). The Pedagogy of Community-Based Learning. what is it AND Why do we use it?. 3rd Annual Symposium. New Methods of Education. CommunityBased Learning. An-Najah National University.

Graves, K. (2008). The language curriculum: A social contextual perspective. Language Teaching, 41(2), 147-181. https://doi.org/10.1017/ S0261444807004867

Gupta, A. (2006). Early experiences and personal funds of knowledge and beliefs of immigrant and minority teacher candidates dialog with theories of child development in a teacher education classroom. Journal of Early Childhood TeacherEducation, 27(1), 3-18. https://doi.org/10.1080/10901020500534224

Kretzmann, J. P., \& McKnight, J. (1993). Building communities from the inside out: A path toward finding and mobilizing a community's assets. Evanston, IL: Chicago, IL: Asset-Based Community Development Institute, Institute for Policy Research, Northwestern University.

Lave, J., \& Wenger, E. (1991). Situated learning: Legitimate peripheral participation. Cambridge: Cambridge University. https://doi.org/10.1017/ CBO9780511815355 
López, J. K. (2010). Funds of knowlege. Learn NC Retrieved 9 March 2010, from www.learnnc.org.

Matus, C., EMcCarthy, C. (2003). The triumph of multiplicity and the carnival of difference: Curriculum dilemmas in the age of postcolonialism and globalization. In W. Pinar (Ed.), International handbook of curriculum research (pp. 73-82). London: Lawrence Erlbaum Associates.

Medina, R. A, Ramirez, L., E Clavijo, A. (2015). Reading the community critically in the digital age: A multiliteracies approach. In P. Chamness Miller., M. Mantero. \& H. Hendo (Eds.), ISLS readings in language studies (pp. 45-66). Grandville, MI: International Society for Language Studies.

Moll, L., Amanti, C., Neff, D., \& Gonzalez, N. (1992). Funds of knowledge for teaching: Using a qualitative approach to connect homes and classrooms. Qualitative Issues in Educational Research Theory into Practice, 31(2), 132-141. https://doi. org/10.1080/00405849209543534

Murrell, P. (2001). The community teacher: A new framework for effective urban teaching. NewYork, NY: Teachers College Press.

Oughton, H. (2010). Funds of knowledge-a conceptual critique. Studies in the Education of Adults, 42(1), 63-78. https://doi.org/10.1080/02660830.2010.116 61589

Rincón J., \& Clavijo-Olarte A. (2016). Fostering EFL learners' literacies through local inquiry in a multimodal experience. Colombian Applied Linguistics Journal, 18(2), 67-82. https://doi. org/10.14483/calj.v18n2.10610
Schecter, S., Solomon, P., \& Kittmer, L. (2003). Integrating teacher education in a community situated school agenda. In S. Schecter \& J. Cummins (Eds.), Multilingual education in practice: Using diversity as a resource (pp. 81-89). Portsmouth, $\mathrm{NH}$ : Heinemann.

Sharkey, J., (2012). Community-based pedagogies and literacies in language teacher education: Promising beginnings, intriguing challenges. Ikala: Revista de Lenguaje y Cultura, 17(1), 9-13.

Sharkey, J., \& Clavijo-Olarte, A. (2012). Promoting the value of local knowledge in ESLEFL teacher education through community-based field assignments. In B. Medrado \& C. Reichmann (Eds.), Projetos e praticas na formacao de professors de lingua inglesa. Paraiba: Brasil. Editora Universitaria UFPB.

Sinclair, B., McGrath, I., \& Lamb, T. (1999). Learner autonomy, teacher autonomy: Future Directions. Edinburgh: Longman.

Suleman, Q., Hussan, D., Shakir, M., Akhtar, S., Hussain, I., Akhtar, Z., \& Khan, W. (2012). Effects of family structure on the academic achievement of students at elementary level in Karak District, Pakistan. Journal of Sociological Research, 3(2), 234-247. https://doi. org/10.5296/jsr.v3i2.2358

Warburton, H., \& Martin, A. M. (1999). Local people's knowledge: Best practice guideline. SocioEconomic Methodologies Programme. London, DFID.

Wenger, E. (1998). Communities of practice: Learning, meaning, and identity. Cambridge University Press. https://doi.org/10.1017/CBO9780511803932 


\section{Appendix A}

\section{Valuing Difference}

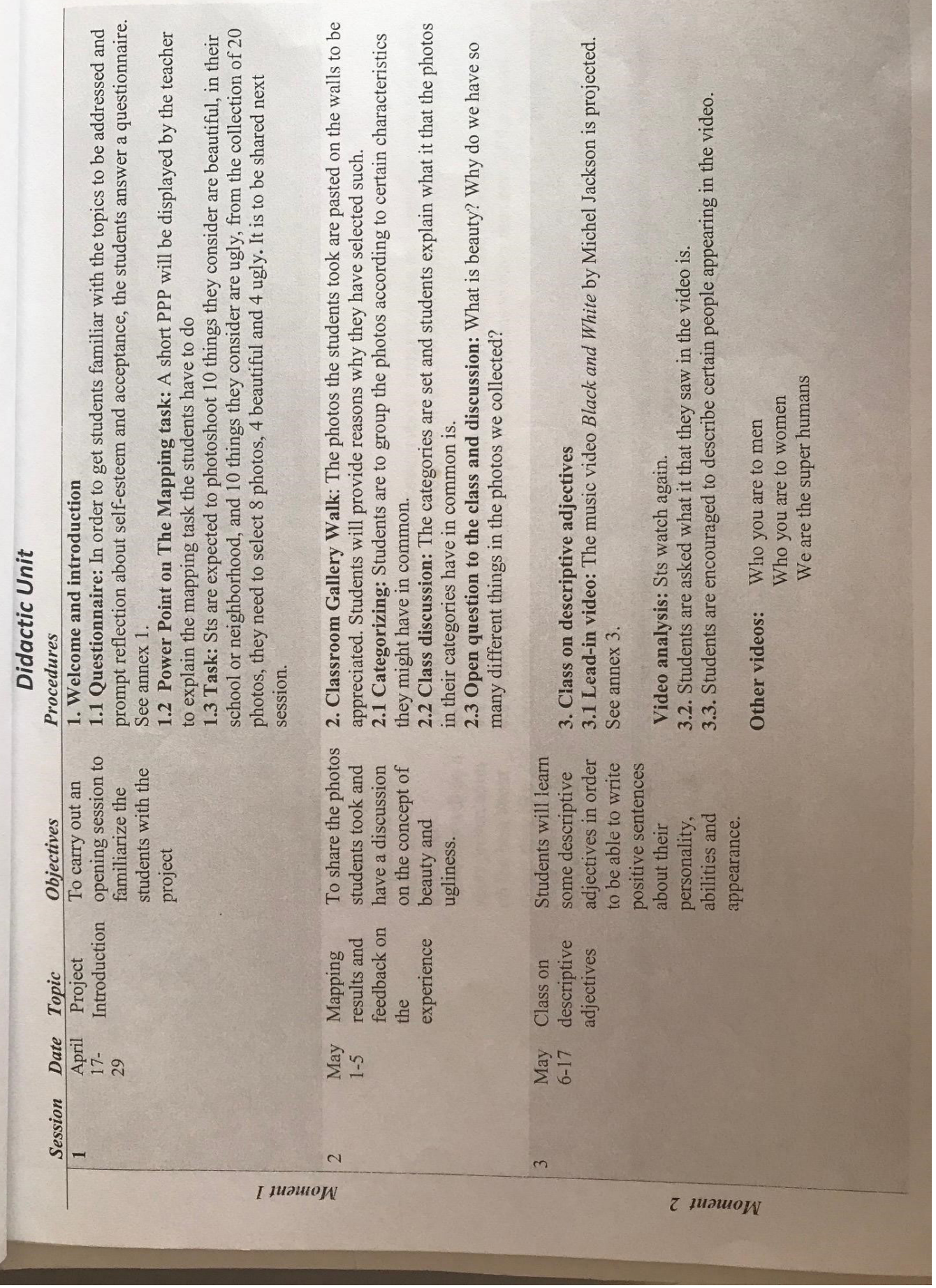




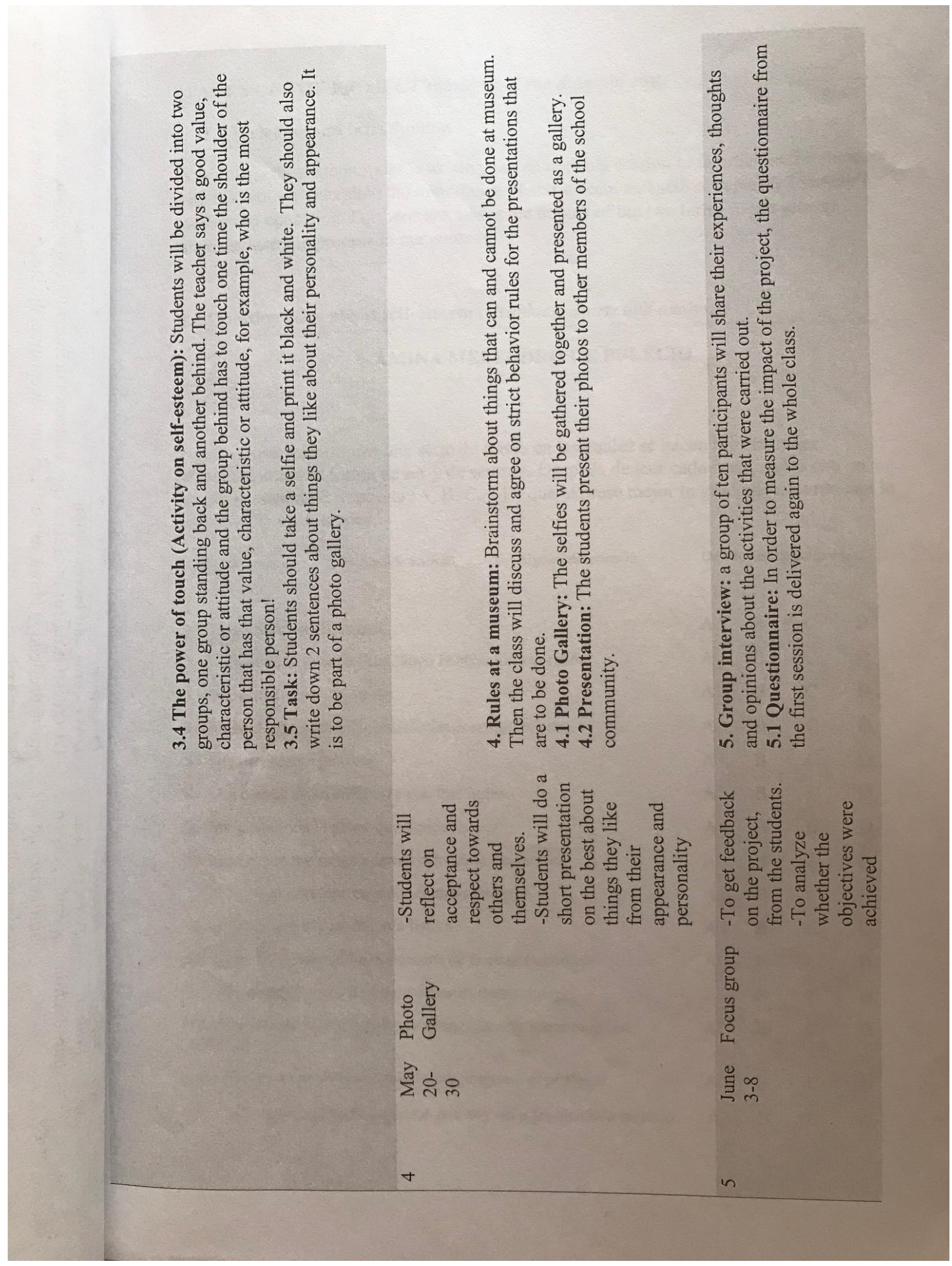




\section{Appendix B}

Family Structure's Effects on Eighth Grader's Performance from a Public School

\begin{tabular}{|c|c|c|}
\hline WEX & ACIIVIY / DESCRIIION & OBEECIVE \\
\hline 1 ( 10 minutes) & 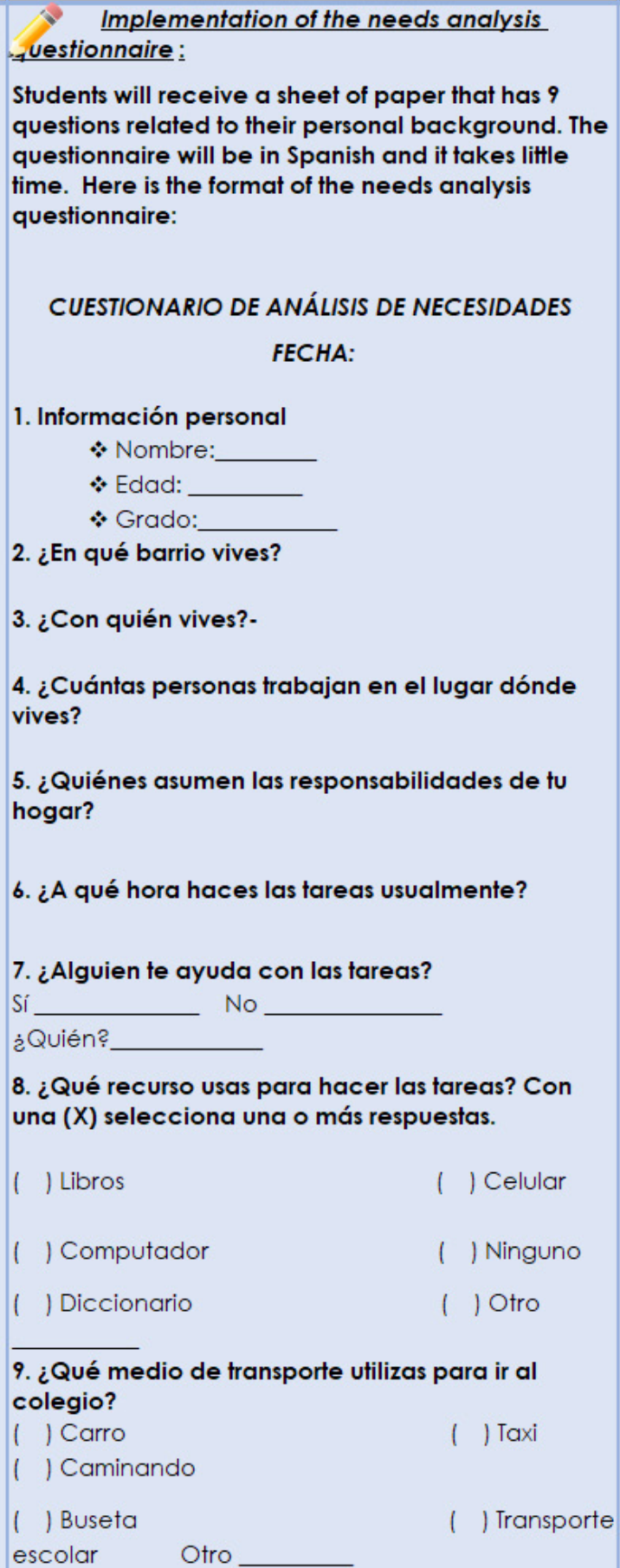 & $\begin{array}{l}\text { To get information a about } \\
\text { the students' fa family structure. }\end{array}$ \\
\hline
\end{tabular}




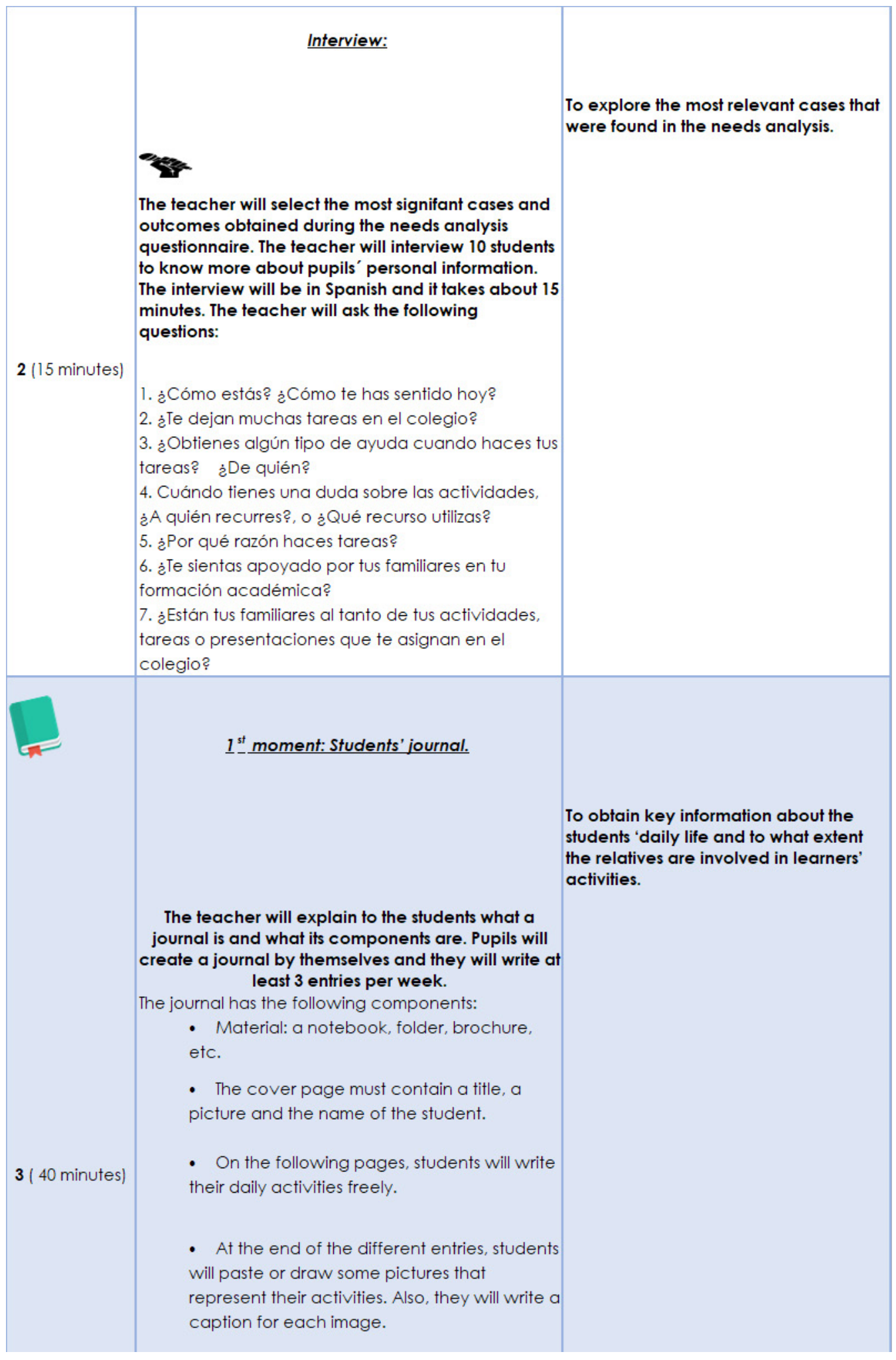




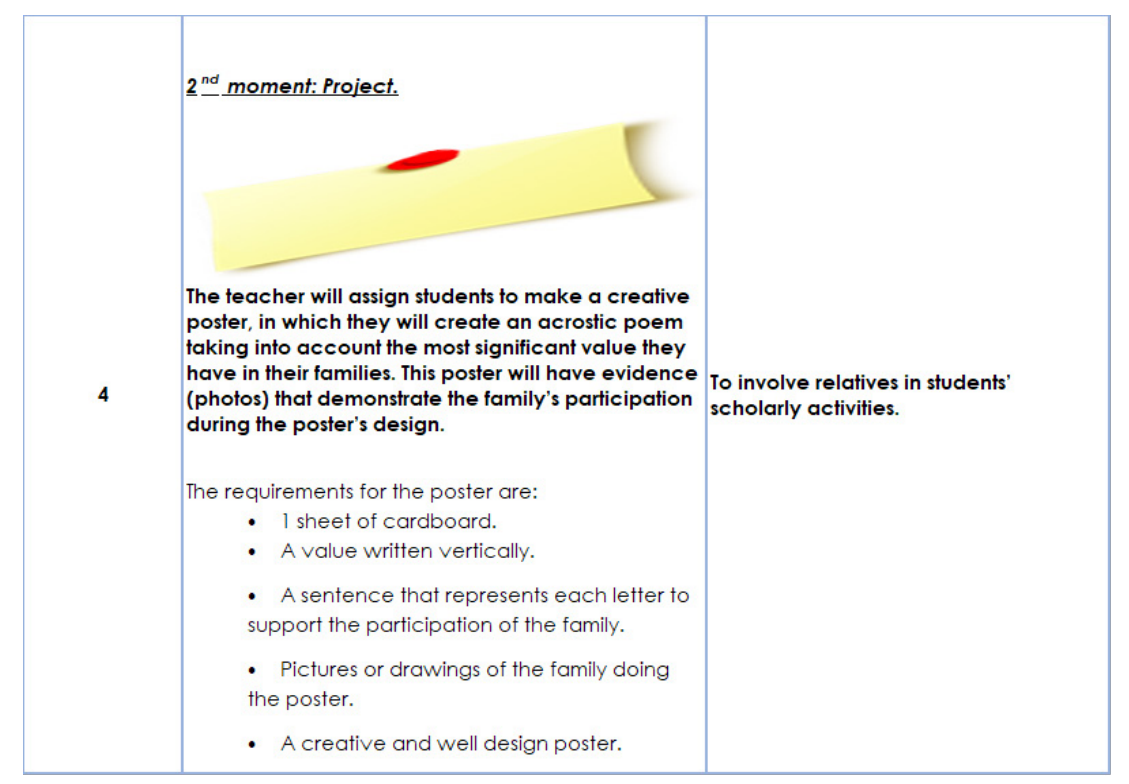

\begin{tabular}{|c|c|c|c|c|}
\hline $\begin{array}{l}\text { ESTÁNDARES } \\
\text { BÁSICOS } \\
\text { SECUNDARIA }\end{array}$ & $\begin{array}{l}\text { GRADO : } \\
\text { OCTAVO }\end{array}$ & $\begin{array}{c}\text { ÁREA : } \\
\text { IDIOMA } \\
\text { EXTRANJERO }\end{array}$ & $\begin{array}{l}\text { ASIGNATURA: } \\
\text { INGLÉS }\end{array}$ & $\begin{array}{l}\text { PRE INTERMEDIO I } \\
\text { ( B I.I ) }\end{array}$ \\
\hline \multicolumn{5}{|l|}{ INDICADORES } \\
\hline 1. ESCUCHA & 2. LECTURA & 3. ESCRITURA & $\begin{array}{l}\text { 4.MONOLÓGO } \\
\text { S }\end{array}$ & 5.CONVERSACIÓN \\
\hline \multirow[t]{3}{*}{$\begin{array}{l}\text { Identifico } \\
\text { diferentes roles } \\
\text { de los hablantes } \\
\text { que participan en } \\
\text { conversaciones } \\
\text { de temas } \\
\text { relacionados con } \\
\text { mis intereses. }\end{array}$} & $\begin{array}{l}\text { Identifico } \\
\text { relaciones de } \\
\text { significado } \\
\text { expresadas } \\
\text { en textos } \\
\text { sobre temas } \\
\text { que me son } \\
\text { familiares. }\end{array}$ & $\begin{array}{l}\text { Escribo } \\
\text { narraciones } \\
\text { sobre } \\
\text { experiencias } \\
\text { personales y } \\
\text { hechos a mi } \\
\text { alrededor. }\end{array}$ & $\begin{array}{l}\text { Hago } \\
\text { presentacion } \\
\text { es cortas y } \\
\text { ensayadas } \\
\text { sobre temas } \\
\text { cotidianos y } \\
\text { personales. }\end{array}$ & $\begin{array}{l}\text { Converso con mis } \\
\text { compañeros y mi } \\
\text { profesor } \\
\text { experiencias } \\
\text { pasadas } \\
\text { planes futuros. }\end{array}$ \\
\hline & & $\begin{array}{l}\text { Diligencio } \\
\text { efectivament } \\
\text { e formatos } \\
\text { con } \\
\text { información } \\
\text { personal. }\end{array}$ & $\begin{array}{l}\text { Narro historias } \\
\text { cortas } \\
\text { enlazando } \\
\text { mis ideas de } \\
\text { manera } \\
\text { apropiada. }\end{array}$ & $\begin{array}{l}\text { Me apoyo en mis } \\
\text { conocimientos } \\
\text { generales del } \\
\text { mundo para } \\
\text { participar en una } \\
\text { conversación. }\end{array}$ \\
\hline & & $\begin{array}{l}\text { Produzco } \\
\text { textos } \\
\text { sencillos con } \\
\text { diferentes } \\
\text { funciones } \\
\text { (describir, } \\
\text { narrar, } \\
\text { argumentar) } \\
\text { sobre temas } \\
\text { personales y } \\
\text { relacionados } \\
\text { con otras } \\
\text { asignaturas. }\end{array}$ & $\begin{array}{l}\text { Hago } \\
\text { descripciones } \\
\text { sencillas } \\
\text { sobre } \\
\text { diversos } \\
\text { asuntos } \\
\text { cotidianos de } \\
\text { mi entorno. }\end{array}$ & \\
\hline
\end{tabular}




\begin{tabular}{|c|c|}
\hline BASIC LEARNING RIGHTS - ENGLISH & EIGHTH GRADE \\
\hline $\begin{array}{l}\text { Makes recommendations to } \\
\text { people in his/her community about } \\
\text { what to do, when and how, based on } \\
\text { daily situations in his or her family life, } \\
\text { school or local environment. }\end{array}$ & $\begin{array}{l}\text { Makes brief presentations on } \\
\text { academic topics related to his/her } \\
\text { school environment or community } \\
\text { including in the presentation: } \\
\text { relevant facts, specific details, and } \\
\text { specific vocabulary pertinent to the } \\
\text { topic. Prior to giving the } \\
\text { presentation, the student prepares } \\
\text { and receives advice from his/her } \\
\text { classmates and/or teacher. }\end{array}$ \\
\hline $\begin{array}{l}\text { Expresses emotions and feelings } \\
\text { about a situation or specific topic } \\
\text { related to his/her family or school and } \\
\text { presents supporting reasons in a clear } \\
\text { and simple manner. }\end{array}$ & $\begin{array}{l}\text { Explains the reasons behind } \\
\text { plans and actions related to his/her } \\
\text { personal, school and community } \\
\text { environment. }\end{array}$ \\
\hline $\begin{array}{l}\text { Briefly narrates current facts, daily } \\
\text { situations or personal experiences } \\
\text { orally and in written form. }\end{array}$ & \\
\hline
\end{tabular}

